ISSN 2623-6575

GLASILO

UDK $502 / 504$

UDK 58

FUTURE

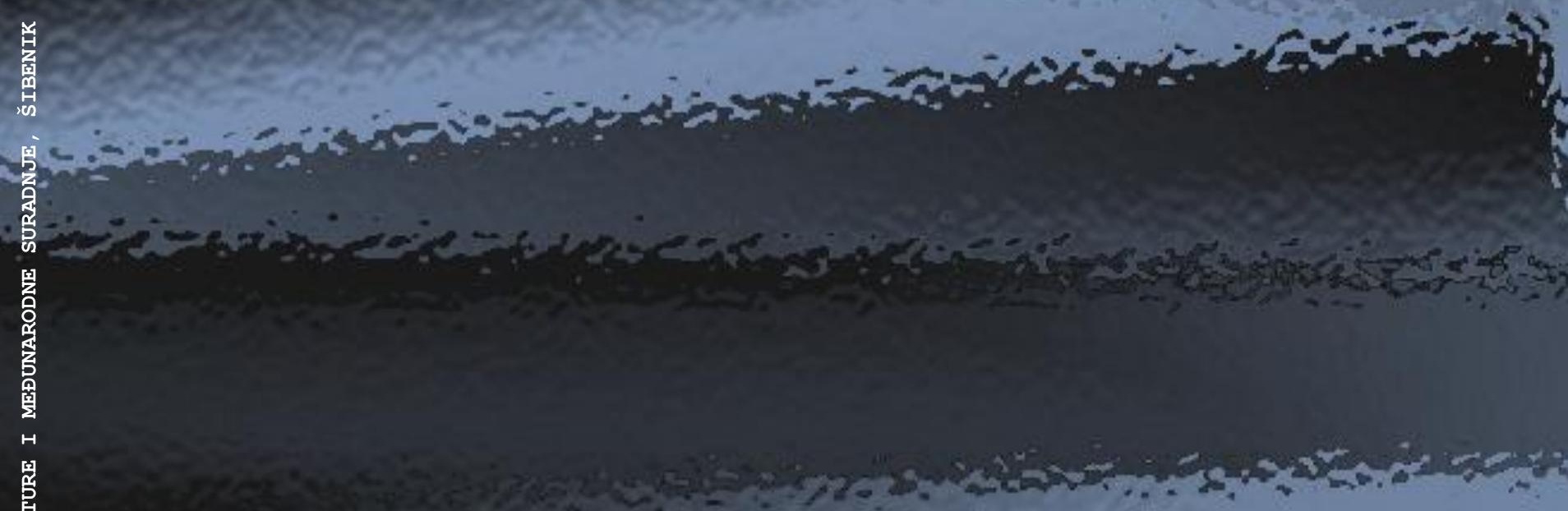

궁

i

$\overbrace{4}^{\circ}$

ठ

㔯

突

递

$\mathbb{4}$

정

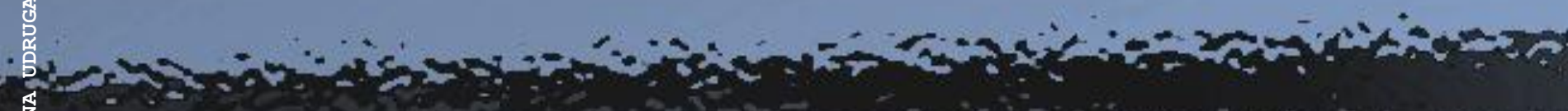

,

焉

钲

否

VOLUMEN 4 BROJ 1

SVIBANJ 2021 . 


\section{Glasilo Future}

\section{Stručno-znanstveni časopis}

\section{Nakladnik: FUTURA \\ F $\mathrm{OT}$ TR $\mathrm{A}$}

Sjedište udruge: Šibenik
Adresa uredništva:

Bana Josipa Jelačića 13 a, 22000 Šibenik, Hrvatska / Croatia

㞗 / 息: +385 (0) 022218133

凹: urednistvo@gazette-future.eu / editors@gazette-future.eu

(3): www.gazette-future.eu

\section{Uređivački odbor / Editorial Board:}

Doc. dr. sc. Boris Dorbić, v. pred. - glavni i odgovorni urednik / Editor-in-Chief

Emilija Friganović, dipl. ing. preh. teh., v. pred. - zamjenica g. i o. urednika / Deputy Editor-in-Chief

Ančica Sečan, mag. act. soc. - tehnička urednica / Technical Editor

Antonia Dorbić, mag. art. - zamjenica tehničke urednice / Deputy Technical Editor

Prof. dr. sc. Željko Španjol

Mr. sc. Milivoj Blažević

Vesna Štibrić, dipl. ing. preh. teh.

Međunarodno uredništvo / International Editorial Board:

Prof. dr. sc. Kiril Bahcevandziev - Portugalska Republika (Instituto Politécnico de Coimbra)

Prof. dr. sc. Martin Bobinac - Republika Srbija (Šumarski fakultet Beograd)

Prof. dr. sc. Zvezda Bogevska - Republika Sjeverna Makedonija (Fakultet za zemjodelski nauki i hrana Skopje)

Dario Bognolo, mag. ing. - Republika Hrvatska (Veleučilište u Rijeci)

Prof. dr. sc. Agata Cieszewska - Republika Poljska (Szkoła Główna Gospodarstwa Wiejskiego w Warszawie)

Dr. sc. Bogdan Cvjetković, prof. emeritus - Republika Hrvatska (Agronomski fakultet Zagreb)

Prof. dr. sc. Duška Ćurić - Republika Hrvatska (Prehrambeno-biotehnološki fakultet Zagreb)

Prof. dr. sc. Margarita Davitkovska - Republika Sjeverna Makedonija (Fakultet za zemjodelski nauki i hrana Skopje)

Prof. dr. sc. Dubravka Dujmović Purgar - Republika Hrvatska (Agronomski fakultet Zagreb)

Prof. dr. sc. Josipa Giljanović - Republika Hrvatska (Kemijsko-tehnološki fakultet u Splitu)

Prof. dr. sc. Semina Hadžiabulić - Bosna i Hercegovina (Agromediteranski fakultet Mostar)

Prof. dr. sc. Péter Honfi - Mađarska (Faculty of Horticultural Science Budapest)

Prof. dr. sc. Mladen Ivić - Bosna i Hercegovina (Univerzitet PIM)

Doc. dr. sc. Anna Jakubczak - Republika Poljska (Uniwersytet Technologiczno-Przyrodniczy w Bydgoszczy)

Doc. dr. sc. Orhan Jašić - Bosna i Hercegovina (Filozofski fakultet Tuzla)

Prof. dr. sc. Tajana Krička - Republika Hrvatska(Agronomski fakultet Zagreb)

Doc. dr. sc. Dejan Kojić - Bosna i Hercegovina (Univerzitet PIM)

Slobodan Kulić, mag. iur. - Republika Srbija (Srpska ornitološka federacija i Confederation ornitologique mondiale)

Prof. dr. sc. Biljana Lazović - Crna Gora (Biotehnički fakultet Podgorica)

Prof. dr. sc. Branka Ljevnaić-Mašić - Republika Srbija (Poljoprivredni fakultet Univerziteta u Novom Sadu)

Doc. dr. sc. Zvonimir Marijanović - Republika Hrvatska (Kemijsko-tehnološki fakultet u Splitu)

Doc. dr. sc. Ana Matin - Republika Hrvatska (Agronomski fakultet Zagreb)

Prof. dr. sc. Bosiljka Mustać - Republika Hrvatska (Sveučilište u Zadru)

Hrv. akademik prof. dr. sc. Stanislav Nakić - Bosna i Hercegovina (Sveučilište Hercegovina Mostar)

Prof. dr. sc. Tatjana Prebeg - Republika Hrvatska (Agronomski fakultet Zagreb)

Prof. dr. sc. Bojan Simovski - Republika Sjeverna Makedonija (Fakultet za šumarski nauki, pejzažna arhitektura i ekoinženering

"Hans Em" Skopje)

Prof. dr. sc. Davor Skejić - Republika Hrvatska (Građevinski fakultet Zagreb)

Prof. dr. sc. Nina Šajna - Republika Slovenija (Fakulteta za naravoslovje in matematiko)

Akademik prof. dr. sc. Refik Šećibović - Bosna i Hercegovina (Visoka škola za turizam i menadžment Konjic)

Prof. dr. sc. Andrej Šušek - Republika Slovenija (Fakulteta za kmetijstvo in biosistemske vede Maribor)

Prof. dr. sc. Elma Temim - Bosna i Hercegovina (Agromediteranski fakultet Mostar)

Mr. sc. Merima Toromanović - Bosna i Hercegovina (Biotehnički fakultet Univerziteta u Bihaću)

Doc. dr. sc. Ivana Vitasović Kosić - Republika Hrvatska (Agronomski fakultet Zagreb) - gostujuća urednica / Guest editor / (2021) 4(1)

Doc. dr. sc. Ana Vujošević - Republika Srbija (Poljoprivredni fakultet Beograd)

Sandra Vuković, mag. ing. - Republika Srbija (Poljoprivredni fakultet Beograd)

Prof. dr. sc. Vesna Židovec - Republika Hrvatska (Agronomski fakultet Zagreb)

Grafička priprema: Ančica Sečan, mag. act. soc.

Objavljeno: 24. svibnja 2021. godine.

Časopis izlazi u elektroničkom izdanju dva puta godišnje, krajem lipnja i svibnja, a predviđena su i dva interdisciplinarna specijalna izdanja tijekom godine iz STEM i ostalih znanstvenih/umjetničkih područja.

Časopis je besplatan. Rukopisi i recenzije se ne vraćaju i ne honoriraju.

Autori/ce su u potpunosti odgovorni/e za sadržaj, kontakt podatke i točnost engleskog jezika.

Umnožavanje (reproduciranje), stavljanje u promet (distribuiranje), priopćavanje javnosti, stavljanje na raspolaganje javnosti odnosno

prerada u bilo kojem obliku nije dopuštena bez pismenog dopuštenja Nakladnika.

Sadržaj objavljen u Glasilu Future može se slobodno koristiti u osobne i obrazovne svrhe uz obvezno navođenje izvora. 


\section{Glasilo Future}

\section{Stručno-znanstveni časopis}

FUTURA - stručno-znanstvena udruga za promicanje održivog razvoja, kulture i međunarodne suradnje, Bana Josipa Jelačića 13 a, 22000 Šibenik, Hrvatska

$$
\text { (2021) } 4 \text { (1) 01-97 }
$$

\section{SADRŽAJ:}

\section{Izvorni znanstveni rad (original scientific paper)}

\section{Ivana Vitasović-Kosić, Lucija Đermek}

Istraživanje korištenja, gospodarenja i zaštite prirodnih dobara u zakonom zaštićenim područjima - stavovi stanovnika rubnih zona PP Medvednica (Zagreb)

Research on the use, management and protection of natural resources in legally protected areas - attitudes of residents of the peripheral zones of the Medvednica

Teja Pintarič, Nina Šajna

Characteristics of heteroblasty in Hladnikia pastinacifolia (Apiaceae), a rare endemic from Slovenia

\section{Pregledni rad (scientific review)}

D. Prlić

Prikaz visinskog gradijenta vegetacije od Malog Platka prema vrhu Snježnika (Hrvatska) A display of the altitudinal vegetation gradient from Mali Platak to the peak of Mt Snježnik (Croatia)

\section{Stručni rad (professional paper)}

\section{J. Juračak, Andreja Martić}

Agroekološke i ekonomske pretpostavke za ekološki uzgoj konoplje za sjeme na području općine Križ

Agro-ecological and economic assumptions for cultivation of organic hemp for seeds in the municipality of Križ

\section{Mara Marić}

Perivoj i vegetacija Vile Čingrija na Boninovu - opservacije terenske nastave treće godine diplomskog studija Povijest Jadrana i Mediterana

The Park and vegetation of Villa Čingrija at Boninovo area - observations from the field teaching of the third year of the graduate study History of the Adriatic and the Mediterranean

\section{Nekategorizirani rad (uncategorised paper)}

V. Šegota, Nina Vuković, A. Alegro

Društvene vijesti i obavijesti

Social news and announcements 
Teja Pintarič, Nina Šajna / Characteristics of heteroblasty in Hladnikia pastinacifolia (Apiaceae), a rare endemic from Slovenia / Glasilo Future (2021) 4 (1) 23-32

\title{
Characteristics of heteroblasty in Hladnikia pastinacifolia (Apiaceae), a rare endemic from Slovenia
}

\author{
Teja Pintarič ${ }^{1}$, Nina Šajna ${ }^{1 *}$
}

izvorni znanstveni rad (original scientific paper)

doi: $10.32779 /$ gf.4.1.2

Citiranje/Citation $^{2}$

\begin{abstract}
Hladnikia pastinacifolia, the most prominent endemic plant species in Slovenia, is rare and protected because it is a stenoendemic and paleoendemic species restricted to area of Trnovski gozd (W Slovenia). However, this species can be found in various habitats. The disparity between the nonspecific habitat preference of the species and its rarity has not been sufficiently explained. Here we focus on the functional morphological features that are most indicative for the ecology of plant species: the anatomical and morphological characteristics of leaves. Hladnikia pastinacifolia exhibits heterophylly during ontogeny (heteroblasty). We aimed to describe and compare the anatomical characteristics of three $H$. pastinacifolia leaf morphotypes among them and in relation to various habitats. Therefore, we compared leaf functional features that are indicative for the ecology of plant species: the thickness of the leaf lamina, the spongy and palisade parenchyma, the thickness of the upper and lower epidermis and the number of leaf stomata in the upper and lower epidermis. These measurements were further used to calculate the ratio between the spongy and palisade parenchyma, leaf stomata index and the density of leaf stomata. We determined that the $H$. pastinacifolia heteroblasty belongs to the Apium-type. Results showed that the five-pinnate leaves were the most distinct type, being the thickest, with the highest numbers of stomata abaxially. When compared among habitats, leaves from the scree habitat were the thickest according to all the tissue layers studied. The indices calculated were less useful for the distinction between leaf types and habitats.
\end{abstract}

Key words: heterophylly, anatomy, leaf thickness, stomata.

\section{Introduction}

Hladnikia pastinacifolia Rchb. (Apiaceae), the most prominent endemic plant species in Slovenian flora, is a stenoendemic, occurring only in a $4 \mathrm{~km}^{2}$ area (Čušin, 2004) restricted to the slopes of the

\footnotetext{
${ }^{1}$ Biology Department, Faculty of Natural Sciences and Mathematics, University of Maribor, Koroška c. 160, SI 2000 Maribor, Republic of Slovenia.

*E-mail: nina.sajna@um.si.

2 Pintarič, T., Šajna, N. (2021). Characteristics of heteroblasty in Hladnikia pastinacifolia (Apiaceae), a rare endemic from Slovenia. Glasilo Future, 4(1), 23-32.
} 
Trnovski gozd high karst plateau in the south-western part of Slovenia. It is a paleoendemic, having survived the last glaciations in situ (Šajna et al., 2012). Hladnikia pastinacifolia is a small growing species of the Apiaceae family, with a leafy rosette for most of its monocarpic life-cycle. This means that the plant remains in its vegetative state for several years until it flowers and produces seeds (Šajna et al., 2018), which happens only once in a lifetime, whereupon the plant dies. Generally, high interest in this species exists because it represents an endemic monotypic genus with unique evolution. Because of the narrow distribution range rarity, this species is listed as a Natura 2000 species and is strictly protected.

However, it is difficult to understand why the species is rare, since it thrives successfully in various habitats differing in the nature of the disturbance and the prevailing stress and such habitats are common across the species' distribution range. It can be found in rock crevices, stony grassland patches, screes, active stony pastures, man-made stone walls, and even on one site in gravel at the road verge. Because the disparity between the non-specific habitat preference of the species and its rarity has been insufficiently explained, it is necessary to evaluate plant functional features that are indicative for the ecology of plant species: the anatomical and morphological characteristics of leaves.

Leaf size and shape influence critical leaf functions (leaf temperature, transpiration, photosynthesis) and can have significant consequences for plant fitness (Winn, 1999). Leaf variation in size and shape along the shoot axis of an individual plant is named heterophylly. There are several mechanisms responsible for heterophylly: phenotypic plasticity resulting from adaptation to environmental factors during leaf development (e.g. sun vs. shade leaves); developmental instability if a plant experiences random environmental heterogeneity (e.g. leaves developed during drought vs. optimal conditions); and heteroblasty - programmed ontogenetic change in shoot morphology (Winn 1999 and references therein). Representatives of the Apiaceae subfamily Apioidae often exhibit heteroblasty to a great extent (Naumov, 2010). They produce different leaves during their various ontogenetic stages; usually, simple leaves become gradually more compound and multisected with each ontogenetic stage (Chang, 2004).

As stressed by Winn (1999) and Vogel (2009), in contrast to the literature describing patterns of heterophylly, we need empirical data to sort out the ecological significance of heterophylly. Therefore, our goal was to assess the ecological significance of heteroblasty in $H$. pastinacifolia leaves by studying the anatomical differences between different leaf morphotypes. We expected to elucidate how variable leaves of $H$. pastinacifolia are and how their variability corresponds to the various $H$. pastinacifolia habitats. Naumov (2010) described several typologies of multisect leaves in common Apioidae. Therefore, we first aimed to describe the typology of $H$. pastinacifolia heterophylly (heteroblasty) according to Naumov (2010). The second aim was to compare three leaf morphotypes in H. pastinacifolia according to their anatomic characteristics: the thickness of the leaf lamina, the 
Teja Pintarič, Nina Šajna / Characteristics of heteroblasty in Hladnikia pastinacifolia (Apiaceae), a rare endemic from Slovenia / Glasilo Future (2021) 4 (1) 23-32

spongy and palisade parenchyma, the epidermis, and the number of stomata (along with the stomata index (SI) and stomata density (SD)). Additionally, we compared the anatomy of three morphotypes in relation to contrasting habitats where the plants grew: rock crevices, scree, and a man-made stone wall, within each particular habitat and among them.

\section{Methods}

\section{Study species}

Because Hladnikia pastinacifolia Rchb. (Apiaceae; Figure 1) has been described in detail in several publications (Šajna et al., 2012, Šajna et al., 2014, Šajna et al., 2019), here we present only a short description. The species is a monocarpic perennial. Several seasons elapse before the single flowering event. These herbaceous plants are 15-30 cm high. For most of their life, they form a basal rosette of numerous glossy, leathery leaves. At first, only one compound umbel is formed on a rather short stalk. Subsequently, additional flowering shoots branch, protruding from the axil, and each forms a lateral compound umbel of the second order. Occasionally, third order umbels develop on those shoots. On average, a single umbel consists of twenty rays and is supported by a multifoliate involucre. The heartshaped petals are white and small (1 mm long). Plants grow a long, lignified rootstock. The fruit is a typical schizocarp, $4 \mathrm{~mm}$ long and $2 \mathrm{~mm}$ wide.

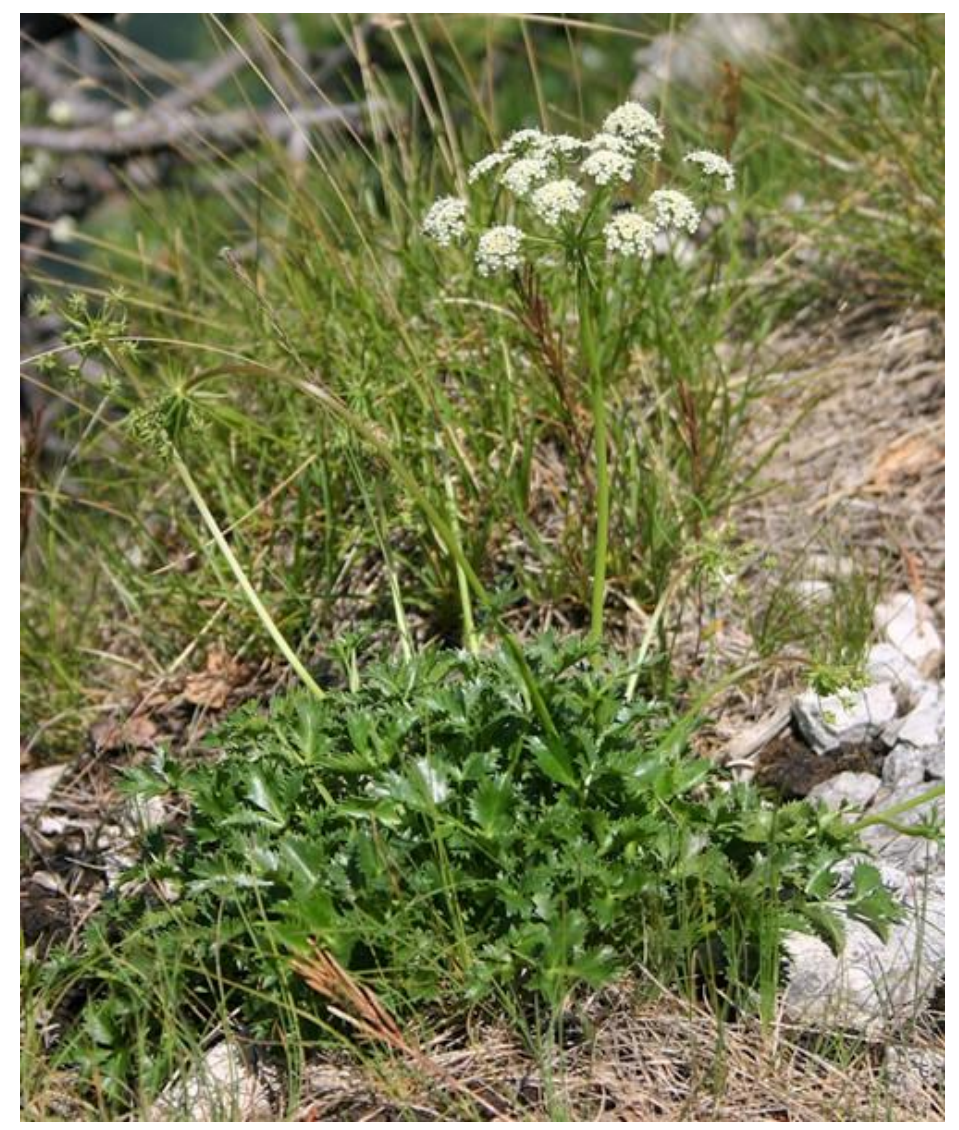

Figure 1. Hladnikia pastinacifolia Rchb. (Apiaceae) habitus (photo: N. Šajna). 


\section{Leaf anatomy study}

For preparation of the microscope slides, we used material fixed with FAA (formalin-acetic acidalcohol). Leaves were taken from different plants randomly. Each leaf was used either for a crosssection or for epidermis peel (for numeri of categorized samples see Table 2 and Table 3). Simple leaves were sampled whole because of the small size, while for three- and five-pinnate leaves only the terminal leaflet was sampled. For each leaf/leaflet we made one cross-section at its widest part, which was measured once choosing a homogenous part, avoiding vascular bundles. Cross-sections were performed by hand and observed in water. We studied sections under the Nikon Eclipse 50i microscope and performed measurements with Eclipse Net software (Nikon, Waver, Belgium). We measured the thickness of the leaf lamina, the spongy and palisade parenchyma, the thickness of the upper and lower epidermis. The measurement data was further used to calculate the ratio between the spongy and palisade parenchyma.

For stomata observations under the microscope, we made abaxial and adaxial epidermis peels. We counted stomata and epidermal cells for a visual field at a magnification of $4000 \mathrm{x}$ and applied it to calculations of stomata density (SD; number of stomata per $1 \mathrm{~mm}^{2}$ ), density of epidermal cells (ED; number of epidermal cells per $\left.1 \mathrm{~mm}^{2}\right)$ and stomata index (SI \% $\left.=\mathrm{SD} /(\mathrm{SD}+\mathrm{ED}) * 100\right)$.

Statistical analysis included a comparison of leaf characteristics according to different morphotypes and according to different habitats with one-way analysis of variance - ANOVA, followed by the posterior Tukey Honest Significant Difference (HDS) test for unequal samples. For comparisons of all leaf morphotypes across all habitats factorial ANOVA was used for all listed anatomical features. Tests were performed with Statistica software (Statsoft).

\section{Results}

\section{Description of heteroblasty in Hladnikia pastinacifolia}

During ontogenetic development, the area of the leaf blade of the rosette leaf increases its complexity (Figure 2). The first true leaf of a juvenile plant is simple, sometimes slightly three-lobed. In the next leaf, the lobes become more deeply indented to form a ternate leaf with three segments. The subsequent leaf develops five segments, where the top segment has three lobes. We also observed the leaves of the floral shoot exhibiting the opposite pattern: their size and complexity decreased, with each series occurring higher on the shoot; however, these leaves were not included in our study. 

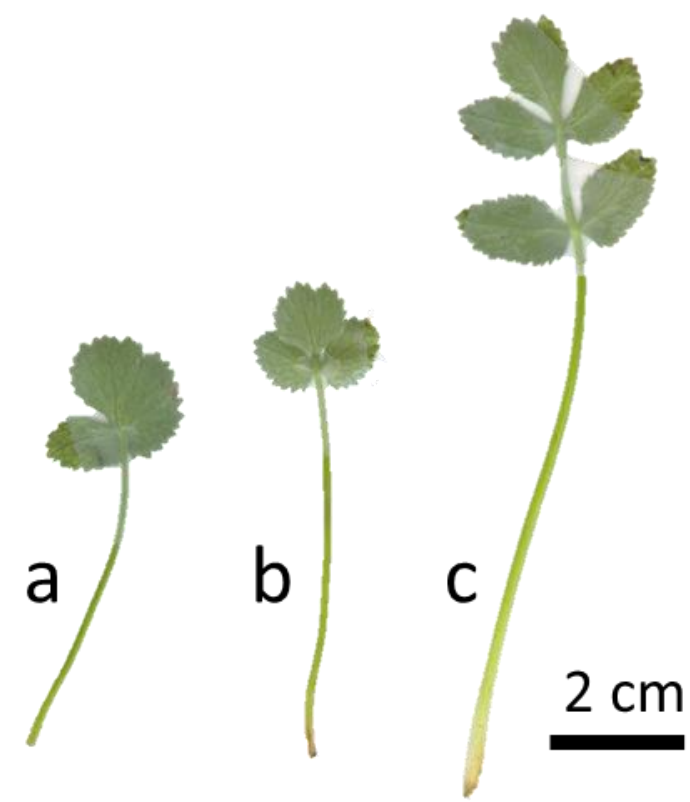

Figure 2. Heteroblasty in Hladnikia pastinacifolia: a) simple leaf, b) ternate leaf, c) odd-pinnate leaf (photo: N. Šajna).

\section{Leaf anatomy comparisons}

The three leaf morphotypes differed significantly in leaf thickness as well as in the thickness of the palisade and spongy tissue layer (one-way ANOVA, $\mathrm{p}<0.05$; Table 1). For most of the measured parameters, leaf type 3 had higher values, meaning that these leaves were thicker, the reason for which was mainly the thicker spongy parenchyma. The calculated indices turned out to be less powerful descriptors, since these were similar for all leaf types (Table 1).

Based on the differences in epidermal cells and stomata, only leaf type 3 was significantly different with regard to the stomata number abaxially (one-way ANOVA, $\mathrm{F}_{2,25}=5.58, \mathrm{p}<0.01$; Table 1). We observed a trend towards an increase in stomata numbers from leaf type 1 to leaf type 3 abaxially as well as adaxially, whereby stomata size did not change among leaf types. We expected the stomata index to correspond with these results; however, it does so only for the adaxial side, although not a statistically significant finding. 
Table 1. Basic statistics of leaf thickness (measured as a whole and divided into tissue parts), epidermal cells and stomata density and calculated ratios and stomatal indices for three leaf morphotypes in Hladnikia pastinacifolia (type 1 - simple leaf blade, 2 - leaf blade with 3 segments, 3 - leaf blade with 5 segments). Numbers marked in bold were significantly different (ANOVA, $\mathrm{p}<0.05$ ), different letters indicate differences revealed by the Tukey HSD test. ave=Mean, N=numerus, s.d.=standard deviation.

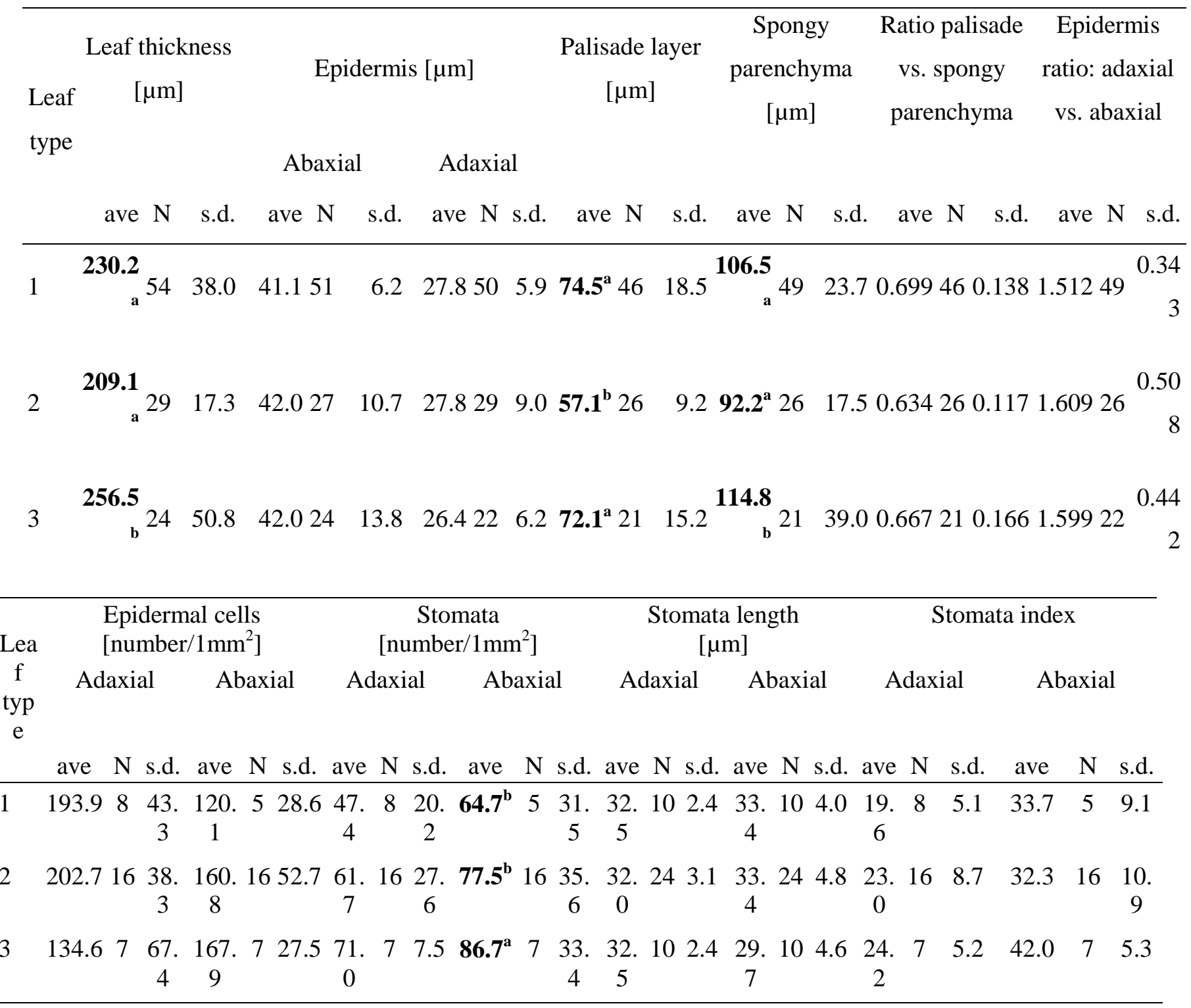

When we considered the three leaf types by contrasting habitats (rock crevices, scree, and man-made stone wall; Table 2), the habitat accounts for the $26.3 \%$ of variance in the morphological features (factorial ANOVA, $\mathrm{F}_{7,75}=3.82, \mathrm{p}=0.01$ ). There is also a significant interaction between the leaf type and habitat (factorial ANOVA, $\mathrm{F}_{21,216}=1.71, \mathrm{p}=0.03$ ), whereby the interaction explains $14.2 \%$ of variance in the studied features. The leaves differed significantly in leaf blade thickness (one-way ANOVA, $\mathrm{F}_{7,99}=54.43$, $\mathrm{p}<0.01$ ), adaxial (one-way ANOVA, $\mathrm{F}_{7,94}=4.08, \mathrm{p}<0.01$ ) and abaxial epidermis (one-way ANOVA, $\mathrm{F}_{7,93}=2.95, \mathrm{p}<0.01$ ), palisade layer (one-way ANOVA, $\mathrm{F}_{7,85}=16.79, \mathrm{p}<0.01$ ) and 
spongy parenchyma (one-way ANOVA, $\mathrm{F}_{7,88}=22.28, \mathrm{p}<0.01$ ). As with Table 1 , the calculated indices could not distinguish between leaf types. Results of factorial ANOVA showed that all studied leaf tissue layers of the simple and odd-pinnate leaves from the scree habitat were thicker compared to leaves from other habitats. The spongy parenchyma thickness contributed most to the high thickness measurements, followed by the palisade layer thickness. Leaves from rock crevices and the man-made stone wall did not differ significantly in thickness. Leaf thickness increases from the simple leaf to the odd-pinnate leaf in all habitats except for the man-made stone wall. In the latter habitat, leaves, irrespective of leaf type, had the thinnest epidermis, adaxially as well as abaxially.

Table 2. Basic statistics of measured and calculated data for leaf thickness (measured as a whole and divided into tissue parts) and calculated ratios of three leaf morphotypes (LM) in Hladnikia pastinacifolia (type 1 - simple leaf blade, 2 - leaf blade with 3 segments, 3 - leaf blade with 5 segments) in different habitats $(1$ - rock crevices, 2 - scree, 3 - man-made stone wall). ave=Mean $\mathrm{N}=$ numerus, s.d.=standard deviation.

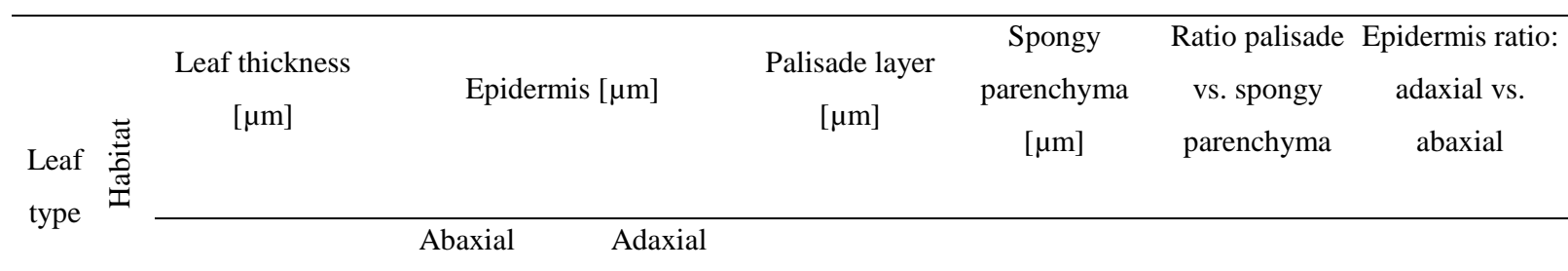

\begin{tabular}{rrrrrrrrrrrrrrrrrrrrrrrrrrrrr}
\hline 1 & 1 & $\mathbf{2 0 4 . 6}$ & 31 & 15.3 & $\mathbf{4 1 . 6}$ & 27 & 6.5 & $\mathbf{2 7 . 6}$ & 27 & 6.0 & $\mathbf{6 4 . 6}$ & 24 & 9.8 & $\mathbf{9 1 . 4}$ & 27 & 11.9 & 0.7 & 24 & 0.14 & 1.54 & 26 & 0.38 \\
1 & 2 & $\mathbf{2 7 6 . 9}$ & 18 & 23.0 & $\mathbf{4 2 . 0}$ & 19 & 5.6 & $\mathbf{3 0 . 1}$ & 18 & 4.3 & $\mathbf{9 0 . 6}$ & 17 & 19.0 & $\mathbf{1 3 2 . 6}$ & 17 & 16.8 & 0.7 & 17 & 0.15 & 1.40 & 18 & 0.25 \\
1 & 3 & $\mathbf{2 2 0 . 1}$ & 5 & 9.3 & $\mathbf{3 5 . 3}$ & 5 & 3.5 & $\mathbf{2 0 . 7}$ & 5 & 4.4 & $\mathbf{6 7 . 9}$ & 5 & 10.3 & $\mathbf{9 9 . 2}$ & 5 & 15.2 & 0.7 & 5 & 0.10 & 1.75 & 5 & 0.31 \\
2 & 1 & $\mathbf{2 0 8 . 5}$ & 16 & 19.0 & $\mathbf{4 7 . 3}$ & 15 & 11.3 & $\mathbf{3 1 . 3}$ & 15 & 10.4 & $\mathbf{5 2 . 7}$ & 12 & 8.2 & $\mathbf{8 4 . 6}$ & 12 & 19.1 & 0.6 & 12 & 0.13 & 1.68 & 14 & 0.65 \\
2 & 3 & $\mathbf{2 0 9 . 8}$ & 13 & 15.8 & $\mathbf{3 5 . 3}$ & 12 & 4.2 & $\mathbf{2 4 . 1}$ & 14 & 4.9 & $\mathbf{6 0 . 9}$ & 14 & 8.5 & $\mathbf{9 8 . 7}$ & 14 & 13.4 & 0.6 & 14 & 0.11 & 1.52 & 12 & 0.26 \\
3 & 1 & $\mathbf{2 2 2 . 5}$ & 4 & 52.2 & $\mathbf{4 2 . 4}$ & 4 & 5.5 & $\mathbf{2 7 . 4}$ & 4 & 5.9 & $\mathbf{5 5 . 6}$ & 3 & 2.4 & $\mathbf{8 0 . 3}$ & 3 & 15.2 & 0.7 & 3 & 0.14 & 1.65 & 4 & 0.63 \\
3 & 2 & $\mathbf{3 0 1 . 0}$ & 12 & 13.2 & $\mathbf{4 7 . 6}$ & 12 & 16.1 & $\mathbf{2 8 . 3}$ & 10 & 7.1 & $\mathbf{8 3 . 7}$ & 11 & 9.2 & $\mathbf{1 4 4 . 3}$ & 11 & 30.0 & 0.6 & 11 & 0.16 & 1.70 & 10 & 0.37 \\
3 & 3 & $\mathbf{2 0 6 . 6}$ & 8 & 11.8 & $\mathbf{3 3 . 2}$ & 8 & 8.2 & $\mathbf{2 3 . 5}$ & 8 & 4.6 & $\mathbf{6 0 . 8}$ & 7 & 9.5 & $\mathbf{8 3 . 3}$ & 7 & 12.1 & 0.7 & 7 & 0.17 & 1.44 & 8 & 0.44 \\
\hline
\end{tabular}

The results again showed that leaf types from various habitats differed significantly in terms of epidermal cells and stomata (Table 3), in the number of epidermis cells abaxially (one-way ANOVA, $\mathrm{F}_{6,21}=3.20, \mathrm{p}=0.02$ ), the number of stomata adaxially (one-way ANOVA, $\mathrm{F}_{6,24}=5.34, \mathrm{p}=0.01$ ) and abaxially (one-way ANOVA, $\mathrm{F}_{6,21}=3.36, \mathrm{p}=0.02$ ), as well as in the stomata index for the adaxial side (one-way ANOVA, $\mathrm{F}_{6,24}=5.7, \mathrm{p}<0.01$ ). According to factorial ANOVA, this was particularly true if leaf type 3 was compared with leaf type 1 , and if it belonged to the scree habitat. The most valuable indicator was the stomata number abaxially. Its value was significantly higher for leaf type 3 from the scree habitat, compared to all other types in various habitats. 
Table 3. Basic statistics of measured and calculated data for leaf stomata characteristics of three leaf morphotypes (LM) in Hladnikia pastinacifolia (type 1 - simple leaf blade, 2 - leaf blade with 3 segments, 3 - leaf blade with 5 segments) in different habitats ( 1 - rock crevices, 2 - scree, 3 - manmade stone wall). ave=Mean $\mathrm{N}=$ numerus, $\mathrm{s} . \mathrm{d} .=$ standard deviation.

\begin{tabular}{|c|c|c|c|c|c|c|c|c|c|c|c|c|c|c|c|c|c|c|c|c|c|c|c|c|c|}
\hline \multirow[t]{3}{*}{ LM } & \multirow{3}{*}{ 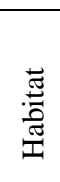 } & \multicolumn{6}{|c|}{$\begin{array}{l}\text { Epidermal cells } \\
\left.\text { [number } / 1 \mathrm{~mm}^{2}\right]\end{array}$} & \multicolumn{6}{|c|}{$\begin{array}{c}\text { Stomata } \\
{\left[\text { number } / 1 \mathrm{~mm}^{2}\right]}\end{array}$} & \multicolumn{6}{|c|}{$\begin{array}{l}\text { Stomata length } \\
{[\mu \mathrm{m}]}\end{array}$} & \multicolumn{6}{|c|}{ Stomata index } \\
\hline & & \multicolumn{3}{|c|}{ Adaxial } & \multicolumn{3}{|c|}{ Abaxial } & \multicolumn{3}{|c|}{ Adaxial } & \multicolumn{3}{|c|}{ Abaxial } & \multicolumn{3}{|c|}{ Adaxial } & \multicolumn{3}{|c|}{ Abaxial } & \multicolumn{3}{|c|}{ Adaxial } & \multicolumn{3}{|c|}{ Abaxial } \\
\hline & & ave & $\mathrm{N}$ & s.d. & ave & $\mathrm{N}$ & s.d. & ave & $\mathrm{N}$ & s.d. & Ave & $\mathrm{N}$ & s.d. & ve & $\mathrm{N}$ & s.d. & ve & $\mathrm{N}$ & s.d. & ave & $\mathrm{N}$ & s.d. & ave & $\mathrm{N}$ & s.d. \\
\hline 1 & 1 & 184 & 6 & 43.0 & 0.4 & 4 & 33.1 & 39.8 & 6 & 6.9 & 53.1 & 4 & 20.4 & 32.3 & 8 & 2.6 & 1.9 & 8 & 2.8 & 8.3 & 6 & 4.8 & 0.0 & 4 & 4.5 \\
\hline 1 & 3 & 22 & 2 & 41.6 & 1 & 1 & 0 & 70.2 & 2 & 35.4 & 111.4 & 1 & 0 & .3 & 2 & 1.9 & 7.7 & 2 & & 3.2 & 2 & 6.0 & 8.4 & 1 & - \\
\hline 2 & 1 & 212.4 & 4 & 21.6 & 100.5 & 4 & 22.8 & 30.9 & 4 & 7.9 & & 4 & & 32.4 & 6 & 3.0 & 33.9 & 6 & 4.4 & 12.6 & 4 & 2.2 & 33.1 & 4 & \\
\hline 2 & 2 & 214.7 & 8 & 44.5 & 183.2 & 8 & 52.4 & 65.9 & 8 & 17.2 & 88.3 & 8 & & 32.0 & 12 & 3.5 & 32.3 & 12 & 2.6 & 23.5 & 8 & 3.2 & 32.3 & 8 & 13.4 \\
\hline 2 & 3 & 168.9 & 4 & 15.5 & 176.2 & 4 & 21.2 & 84.1 & 4 & 33.0 & 83.0 & 4 & 32.8 & 31.8 & 6 & 2.7 & 35.1 & 6 & 7.7 & 32.5 & 4 & 9.3 & 31.6 & 4 & 11.0 \\
\hline J & 2 & 246.6 & 5 & 64.5 & 167.6 & 5 & 32.9 & 73.9 & 5 & 6.6 & 131.1 & 5 & 37.6 & 32.7 & 8 & 2.6 & 30.0 & 8 & 4.4 & 23.7 & 5 & 4.0 & 43.5 & 5 & 5.6 \\
\hline . & 3 & 204.6 & 2 & 90.2 & 168.8 & 2 & 14.6 & 63.8 & 2 & 3.9 & 104.3 & 2 & 0.1 & 31.3 & 2 & 0.8 & 28.5 & 2 & 3.6 & 25.3 & 2 & 9.6 & 38.3 & 2 & 2.0 \\
\hline
\end{tabular}

\section{Discussion}

Hladnikia pastinacifolia is a monocarpic species with a life cycle longer than that of a typical biennial. After overwintering, every spring the first leaves developed by $H$. pastinacifolia are those of the basal rosette. The first true leaves are simple, but more complex leaf blades later develop in such a way that the leaflets are positioned at the first order rachises and form odd-pinnate leaves. The typology of $H$. pastinacifolia heteroblasty is similar to the polymorphic series observed, for example, in Apium graveolens L., Pimpinella saxifraga L., Falcaria vulgaris Bernh. and termed by Naumov (2010) the Apium-type.

Heterophylly in $H$. pastinacifolia represents within-individual plasticity including heteroblasty as well as direct response to environmental conditions. Our results show that in addition to morphological differences among leaf morphotypes, anatomical differences also exist. Generally, the plant's ability to harvest light is not limited only by the height of a plant, its growth-form and total leaf area, or its canopy area. Additional limitations include the plant architecture, which determines the spatial distribution of leaves, and the leaf anatomy. Five-pinnate leaves were the thickest among all types, mainly because of the thickness of the spongy parenchyma. Leaf thickness affects the amount of light absorbed by a leaf, and high values are often recognized as decreasing photosynthesis and growth (Garnier et al., 1999). On the other hand, leaf thickness increases the leaf's longevity (Vile et al., 2005 and references therein).

A review by Winn (1999) reported that in general the heterophylly occurs frequently in species where individuals experience extreme variation in environment. This is confirmed by our study, which further indicates the existence of functional differences affecting individual plant performance in relation to the environmental constraints of a particular habitat. Our results show that plants from the 
scree habitat had the thickest leaves. Coarse scree substrate is a very stressful habitat, prone to disturbance of substrate movement, causing erosion or even burial (Pauli et al., 2003). It is beneficial for a plant growing in such an unstable habitat to have more resistant leaves than plants growing in more sheltered rock crevices or on the even more stable and less stressful man-made stone wall. Moreover, H. pastinacifolia experiences strong irradiation in its habitats for most of the day, however, the habitats differ in the cover of other coexisting species (Šajna et al., 2014). This means that in the contrasting habitats, interspecific competition is reduced in comparison to stony pastures or meadows. Our results confirm a hypothesis stated by Šajna et al. (2012) that screes or scree-like habitats are the optimal habitats for $H$. pastinacifolia, since in such habitats the seed production and plant biomass are the highest. Rock crevices represent a marginal substitute habitat.

To conclude, we suggest the need for a general study (morphology and leaf anatomy) to determine the ecological significance of heteroblasty/heterophylly. We have demonstrated that the leaves of $H$. pastinacifolia differ in their anatomy between ontogeny stages and consequently also differ in terms of functionality, both of which are further adapted to the particular habitat where the species grows. We have established that environmental constraints select for an optimum leaf phenotype in each ontogenetic stage within each habitat. We have shown the ecological significance of leaf blade thickness and number of stomata in revealing the most suitable habitat to be a coarse scree-like substrate.

\section{References}

Chang, J., Guan, B., Ge, Y., Chan, Y.G. (2004). Comparative studies on phenotypic plasticity of two herbs, Changium smyrnioides and Anthriscus sylvestris. Journal of Zhejiang University - Science, 5, 656-662.

Čušin, B. (2004). Hladnikia pastinacifolia Rchb. (Hladnikia pastinacifolia Rchb. - rebrinčevolistna hladnikija, hladnikovka). In: Čušin, B. (ed.). Natura 2000 in Slovenia - Plants (Natura 2000 v Sloveniji, Rastline), ZRC SAZU, 107-113.

Garnier, E., Salager, J.L., Laurent, G., Sonie, L. (1999). Relationships between photosynthesis, nitrogen and leaf structure in 14 grass species and their dependence on the basis of expression. New Phytologist, 143, 119-129.

Naumov, S.Y. (2010). Leaf Typology in the subfamily Apioideae (Apiaceae). Plant Diversity and Evolution, 128, 443-454.

Pauli, H., Gottfried, M., Dirnböck, T., Dullinger, S., Grabherr, G. (2003). Assessing the long-term dynamics of endemic plants at summit habitats. In Nagy L., Grabherr G., Körner C., Thompson D.B.A. (eds). Alpine biodiversity in Europe. Berlin: Springer, 195-207. 
Teja Pintarič, Nina Šajna / Characteristics of heteroblasty in Hladnikia pastinacifolia (Apiaceae), a rare endemic from Slovenia / Glasilo Future (2021) 4 (1) 23-32

Šajna, N., Šipek, M., Šuštar-Vozlič, J., Kaligarič, M. (2019). Germination behavior of the extremely rare Hladnikia pastinacifolia Rchb. (Apiaceae)-a Pleistocene in situ survivor. Acta Bot. Croat, 78, $107-115$.

Šajna, N., Kavar, T., Šuštar Vozlič, J., Kaligarič, M. (2012). Population genetics of the narrow endemic Hladnikia pastinacifolia Rchb. (Apiaceae) indicates survival in situ during the Pleistocene. Acta Biologica Cracoviensia. Series Botanica, 54, 84-96.

Šajna, N., Kavar, T., Šuštar Vozlič, J., Kaligarič, M. (2014). New insights into the anatomy of an endemic Hladnikia pastinacifolia Rchb. Acta Bot. Croat., 73, 375-384.

Vile, D., Garnier, E., Shipley, B., Laurent, G., Navas, M.L., Roumet, C., Lavorel, S., Díaz, S., Hodgson, J.G., Lloret, F., Midgley, G.F., Poorter, H., Rutherford, M.C., Wilson, P.J., Wright, I.J. (2005). Specific leaf area and dry matter content estimate thickness in laminar leaves. Annals of Botany, 96, 1129-1136.

Vogel, S. (2009). Leaves in the lowest and highest winds: Temperature, force and shape. New Phytologist, 183, 13-26.

Winn, A.A. (1999). The functional significance and fitness consequences of heterophylly. International Journal of Plant Sciences, 160, S113-S121.

Primljeno: 27. travnja 2021. godine

Prihvaćeno: 17. svibnja 2021. godine
Received: April 27, 2021

Accepted: May 17, 2021 